\title{
IMMIGRATION AND CHILDREN
}

\author{
Burak Katipoğlu ${ }^{1}$, Perihan Şimşek², Abdülkadir Gündüz ${ }^{3}$ \\ ${ }^{1}$ Department of Emergency Medicine, UFuK University Medical Faculty, Dr Ridvan Ege Education and Research Hospital, Ankara, Turkey \\ ${ }^{2}$ Karadeniz Technical University, Faculty of Health Science, Surgery Nursing Department, Trabzon, Turkey \\ ${ }^{3}$ Karadeniz Technical University, Faculty of Medicine, Department of Emergency Medicine, Trabzon, Turkey
}

\begin{abstract}
Various economic, political, environmental and social reasons can force people to migrate, leaving their home. Migration, which is as old as human history, has increased because of some reasons such as globalization, wars and natural disasters. Children have constituted a significant proportion of immigrants. According to the report of the United Nations Children's Fund for 2015, the number of immigrant children living in a different country from the country of their birth is approximately 31 million, of whom about 10 million are refugees around the world.

Children have been obliged to deal with many problems such as hunger, thirst and illness during their migratory journey. In countries to which children migrated to seek asylum, children have been exposed to a great deal of abuse and exploitation, including violence, human trafficking and participation in criminal organisations. Unaccompanied children are especially vulnerable to all these hazards.

The physical and mental health of immigrant children is affected by cultural, geographical and climatic changes. Not knowing the language of the destination country and being unable to communicate with their peers causes an impact of psychological trauma on children. In addition, refugee children living in difficult conditions for a long time are at risk of mental problems and behavioural disorders.
\end{abstract}

KEY WORDS: asylum, child, immigrant child, immigration, refugee

Disaster Emerg Med J 2018; 3(1): 26-30

\section{INTRODUCTION}

"Migration" is the movement of people from one place to another, either within the same country or to another country for the purpose of settling in at that destination [1]. Migration may be done voluntarily to have access to better education opportunities and health care services. On the other hand, people are often forced to migrate due to other circumstances $[2,3]$. Today, the number of forced migrations is increasing in line with the rising number of wars, conflicts, natural disasters, and climate change $[4,5]$. The United Nations Higher Commissioner for Refugees (UNHCR) announced that 65.6 million people were forced to leave their homes and migrate as of the end of 2016 [6].

Children constitute an important part of those who are forced to migrate all over the world. Ac- cording to the data provided by the United $\mathrm{Na}$ tions Children's Fund (UNICEF), almost half of the 3 million Iraqis that were forced to migrate due to the armed conflict in Iraq were children [7]. It was reported that there were around 370,000 children among those who were evacuated from Louisiana due to Hurricane Katrina, which caused the death of many people and severe devastation in the United States in August, 2005 [8]. The Office of the UNHCR reported that more than a million children have had to leave their country because of the armed conflict in South Sudan [9]. During the ongoing Syrian civil war, which has lasted for more than six years, 8.4 million children (about $80 \%$ of Syrian children) were affected. According to the report of the United Nations Refugee Commission in 2015, half of the approximately 4.9 million registered Syrian refugees 
forced to leave their country due to war were children [10]. The conflicts between army and separatist groups in Yemen, the attacks of illegal terrorist organizations and tribal quarrels are pushing people to migrate. In 2015, 169,900 people migrated to neighbouring countries while about 2.5 million people migrated to different regions within the country. The figures show that about $10 \%$ of the country's population was displaced within a year. When it is considered that more than half of Yemen's population is under 19 years of age, the emerging result is that the majority of those who are forced to migrate are children [11]. In Afghanistan, one of the poorest countries in the world, half of the people live under the poverty line. For Afghan children, migration is thus an escape from threats such as terrorist attacks, mine explosions and forced marriages, as well as poverty [12]. According to a report published by the British Parliament (2016-2017), more than half of the unaccompanied children who migrate to European Union countries were Afghan [13]. Libya is at the crossroads for many immigrants trying to flee to Europe from African countries such as Eritrea, Gambia, Nigeria, Egypt and Guinea due to poverty and violence. In September 2016, 256,000 migrants were to be found in Libya. It is has been ascertained that $9 \%$ of these immigrants are children [14]. Myanmar occupies the eighth place on the list of the countries that produces most immigrants in the world according to data obtained by the end of the year 2015. In this country, Muslims who are exposed from the attacks of government forces and Buddhist militants have been forced to migrate to escape from violence, rape and torture [15]. In 2017, the United Nations Children's Fund reported that 60\% of the refugees in Bangladesh were children from Myanmar [16]. In Columbia, armed guerrilla forces kidnap and force children to fight in armed conflicts once they reach the age of eight. Families trying to protect their children from the guerrilla forces have no choice but to migrate. It has been identified that approximately $43 \%$ of the captured guerrillas and $41 \%$ of the guerrillas who were killed in armed conflicts in this country in 2001 were younger than 18 years [17].

\section{CHILDREN AND MIGRATION JOURNEY}

Millions of children, running away from armed conflict, violence, disasters, and poverty, face many dangers on the international migratory routes to

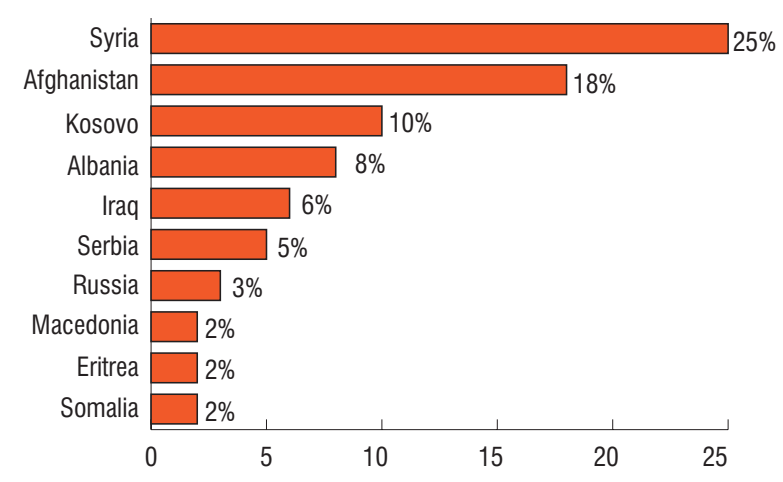

FIGURE 1. Distribution of migrant children seeking asylum from the EU according to their countries of origin (January-September 2015)

reach different countries but mainly to reach Europe (Fig. 1). Since the laws, services, and policies to protect children are insufficient, children are deprived of proper care and protection during these journeys [14]. Human trafficking, kidnapping, forced labour, sexual abuse and death are the most serious dangers that migrant children face while these children are trying to reach other countries to survive. In addition, these children cannot meet their basic needs such as food, housing, and health care services. As a result, they are prone to serious health problems such as infectious diseases, dehydration, pneumonia, and hypothermia $[18,19]$.

Some individual characteristics of these children may increase the risks of their migratory journey. Some of these characteristics are gender, the existence of a physical or mental problem, legal status, nationality, and their being members of ethnic or religious minorities [20]. Moreover, children travelling without any companion and, thus, lacking the care and support of a family are unguarded against all these dangers throughout their journey. In addition, presence of their families does not always guarantee protection for these children against dangers either. Sometimes children are taken into detention with their families and are made to witness their parents being physically or verbally abused [21].

Some routes that migrants follow during their international migratory journeys are very dangerous due to the lack of safety measures. One of the mentioned routes is the Mid-Mediterranean sea route, which is used often to migrate from Africa to Europe [22]. According to the data provided by the International Organization for Migration (IMO), 4,579 people, including 700 children, died while following this route to reach Europe in 2016. The data show that one out of every 40 people who tried to migrate following this 
route died. Likewise, the South-eastern Asia migration route is also very dangerous. During the migration movement from the mountains of Myanmar, one out of every 60 people lost their lives while they were trying to pass through the Bay of Bengal and the Andaman Sea between 2014 and 2015 [19].

\section{UNACCOMPANIED CHILDREN}

Children sometimes start their migration journey alone or lose their relatives along the way. They are likely to get lost and lose their companions especially during the uncontrolled movement of masses while crossing the borders, or on crowded means of transportation [19, 20]. Children, who have to continue their journey alone and not having enough money or the necessary communication skills, are vulnerable to all kinds of abuse, violence, harassment, and exploitation. It is reported that there are many children in the Greek islands, Athens and Italy in a similar situation $[23,24]$.

The rapid increase in the number of unaccompanied migrant children is remarkable worldwide. The number of unaccompanied children coming from Guatemala, Honduras, and El Salvador that sought asylum in the United States increased from 3,304 in 2009, to 51,705 in 2014 [25]. On average, 12,000 children sought asylum in EU member countries annually during 2008-2013; however, this number increased to 96,500 in 2015 [26].

It was determined that unaccompanied migrant children exhibit much more depressive symptoms and carry a heavier burden of stress than other migrant children who are with their relatives in their destination countries. However, these children are able to catch up with the level of success of the other migrant children with respect to their education and work lives [24].

\section{PROBLEMS CHILDREN FACE IN THEIR DESTINATION COUNTRIES}

If the destination country follows accepting and inclusive policies toward migrant children, this facilitates their process of adaptation to their new setting. Moreover, children are still at a risk of involvement to crime, neglect, exploitation, sexual abuse, and violence in their destination countries just as they did during their migratory journey [27]. Children who leave their homes and settle in a new country have to learn a new language and deal with poverty and prejudices. Children, separated from the cultural values of their own societies, may become assimilated during the process of adaptation. On the other hand, migrant children deal with problems meeting their basic needs such as food, shelter and cleanliness, having favourable conditions for their mental and physical development, as well as obtaining an education $[28,29]$.

Although there are some differences among countries, the level of success of migrant children is generally lower than others. These children have serious issues adapting to their current educational institutions, and have a tendency to stay away from their peers and not complete their schooling [30]. These children's lack of communication with both their teachers and friends due to their unfamiliarity with the language of their destination country has been accepted as the main reason for these problems $[28,31]$. It is also emphasized that the socioeconomic disadvantage has a negative effect at this point [32].

It is argued that schools in regions receiving a high number of migrants should receive more resources in order to solve the problems associated with the education of migrant children. It is predicted that if educators socialise with the families of migrant children and their children are able to learn the language of their destination country without forgetting their mother tongues, this would increase their level of success [30].

Migrant children may have to work to survive. This makes it easier for these children to become involved in crime and suffer from violence, as well as accidents while working. Moreover, they spend their entire childhood without any experience of playing, which is crucial for child development. Children should have the opportunity to participate in social and cultural activities, as well as sports, in order to eliminate the risks arising from child labour [33].

Migrant children have been arbitrarily detained thus their freedom has been taken away, in their destination country or the countries that are on the children's migratory route [34]. Children who are forced to share cells with unknown adults sometimes suffer from violence from guardians, police officers, and their adult cell-mate during the detention period. This causes serious physical and psychological trauma to children [35].

The traumas that migrant children can suffer prior to, during, and after their migration deteriorate their mental health and leave deep and permanent wounds on their minds [36]. These children suffer 
from spiritual disharmony, depression, and post-traumatic stress disorder more often than their peers [37].

Turkey has the largest number of refugees in the world. In Turkey, there are more than 3.4 million registered refugees from Syria, Iraq, Afghanistan, Iran, Somalia, and other countries [38]. Syrian children form the majority of these refugees. According to the 2016 report of UNICEF, there are 1.5 million Syrian children in Turkey. Turkey closely collaborates with UNICEF to meet the basic needs of these Syrian children such as protection, education, food, and health care [39].

When countries around the world approved the Convention on the Rights of the Child, all the participatory countries committed to respect and protect the rights of each and every child within their jurisdiction. This means that no matter what their legal status is, all children who seek asylum, or those who are just passing through the country are to have the same rights as other children living within the borders of that country. Despite this commitment, countries have not been able to fully meet their responsibilities of managing mass migratory movements and the protection of children due to lack of resources, capacity, as well as political will [19].

The report of the UNICEF called "Uprooted: The Growing Crisis for Refugee and Migrant Children" points six important initiatives to protect migrant children. These initiatives are as follows [40]:

- Protection of all refugee and migrant children from exploitation and violence, particularly "unaccompanied" migrant children;

- Development of alternative application processes so that children requesting asylum or migrating would not be detained;

- Paying attention towards keeping families together so that children would be protected and would gain legal status;

- Meeting the education, healthcare, and other basic needs of all the refugee and migrant children;

- Determination of the underlying causes for the mass migratory movements and taking action to address these causes;

- Taking the necessary measures to fight xenophobia, discrimination, and marginalisation.

\section{CONCLUSION}

Despite the efforts of institutions such as the United Nations, contracts agreed between countries and the efforts of non-governmental organizations, there is a clear truth, namely that these agreements have not been sufficiently adhered to. The forced migration of children is an increasingly global issue. Problems with this issue can be solved through cooperation of all the world's governments. The basic needs of immigrant children, such as security, education, play, healthy food must be met and children should be provided the opportunity to live with their families. The foster family model is suitable for the protection of unaccompanied children's mental and physical health.

Conflict of interest: None declared

\section{REFERENCES}

1. Yilmaz A. International migration: types, causes and effects. Electronic Turkish Studies. 2014; 9(2): 1686-1703.

2. Özkol Kılınnç K, Özkan ÇG, Kurt Y, Öztürk H. Determination of Self-Esteem Levels of Nursing Students Who Temporarily Migrated. First International Congress of Nursing. Antalya, Türkiye, 3593601, 16-18 March, 2017.

3. Siriwardhana C, Stewart R. Forced migration and mental health: prolonged internal displacement, return migration and resilience. Int Health. 2013; 5(1): 19-23, doi: 10.1093/inthealth/ihs014, indexed in Pubmed: 24029841.

4. Piguet E. Linking climate change, environmental degradation, and migration: a methodological overview. Wiley Interdisciplinary Reviews: Climate Change. 2010; 1(4): 517-524, doi: 10.1002/wcc.54.

5. Greenhill KM. Weapons of Mass Migration: Forced Displacement as an Instrument of Coercion. Strategic Insights. 2010; 9(1): 116-159.

6. United Nations High Commissioner for Refugees (UNCHR). Report. Global trends: Forced displacement in 2016. June 2017, Geneva, Switzerland.

7. United Nations Children's Fund (UNICEF) for every child. Reaching children in Iraq. Children are especially at risk in Iraq crisis. https://www. unicef.org/infobycountry/iraq_74784.htmlAccessed:15/09/2017 (15.09.2017).

8. Reyes $A$. The Immigrant Children of Katrina. Peabody Journal of Education. 2010; 85(4): 443-468, doi: 10.1080/0161956x.2010.518037.

9. United Nations High Commissioner for Refugees (UNCHR). The UN Refugee Agency. More than one million children have fled escalating violence in South Sudan. http://www.unhcr.org/news/ press/2017/5/590c7cb64/million-children-fled-escalating-violence-south-sudan.html (18.09.2017).

10. Nolan D. Children of Syria By the Numbers. http://www.pbs. org/wgbh/frontline/article/children-of-syria-by-the-numbers/ (08.10.2017).

11. UNCHR. Global trends: Forced displacement in 2015. Report. Geneva, Switzerland, June 2016.

12. Riegler $S$. Children on the move dossier. Course of the Preparation of the 3rd International Mayors' Conference NOW Vienna, 30-31 January, 2017. 
13. House of Lords European Union Committee. Children in crisis: Unaccompanied migrant children in the EU. Clerk of the European Union Committee, Committee Office, House of Lords. London, 2nd Report of Session 2016-17.

14. United Nations Children's Fund (UNICEF). The report. A Deadly Journey for Children. The Central Mediterranean Migration Route. February 2017.

15. D'Costa B. Children on the move. Asia's child migrants. UNICEF Office of Research - Innocenti. https://www.unicef-irc.org/article/1424/.

16. Lieby J. UNICEF: More than 200,000 Rohingya children at risk particular concern for the 1,128 documented separated children. UNICEF Australia. https://www.unicef.org.au/about-us/media/september-2017/unicef-more-than-200-000-rohingya-children-at-ris.

17. Ibanez A. Forced displacement in Colombia: Magnitude and causes. The Economics of Peace and Security Journal. 2009; 4(1): 48-54, doi: 10.15355/epsj.4.1.48.

18. United Nations Children's Fund (UNICEF). Migrants in Libya: Insights into the experience of women and children in transit. Briefing Paper Draft. New York, February 2017.

19. United Nations Children's Fund (UNICEF). Report. A child is a child. Protecting children on the move from violence, abuse and exploitation. May 2017.

20. IOM and UNICEF. Data Brief: Migration of Children to Europe 30 November 2015. https://www.iom.int/sites/default/files/press_release/file/IOM-UNICEF-Data-Brief-Refugee-and-Migrant-Crisis-inEurope-30.11.15.pdf (19.09.2017).

21. European Union Committee. Children in crisis: unaccompanied migrant children in the EU 2nd Report of Session 2016-17.

22. Hammond TG. The Mediterranean migration crisis. Foreign Policy Journal. 2015; 1-12.

23. McLeigh J. Protecting Children in the Context of International Migration. Child Abuse \& Neglect. 2013; 37(12): 1056-1068, doi: 10.1016/j.chiabu.2013.10.011.

24. Eide K, Hjern A. Unaccompanied refugee children-vulnerability and agency. Acta Paediatr. 2013; 102(7): 666-668, doi: 10.1111/ apa.12258, indexed in Pubmed: 23560773.

25. Canizales SL. Unaccompanied migrant children: A humanitarian crisis at the US border and beyond. Center for Poverty Research. 2015; 3(4).

26. EUROSTAT News release. Report. Asylum applicants considered to be unaccompanied minors 63,300 unaccompanied minors among asylum seekers registered in the EU in 2016 Over half are Afghans or Syrians. 80/2017-11 May 2017. http://ec.europa.eu/eurostat/ documents/2995521/8016696/3-11052017-AP-EN.pdf/30ca22060db9-4076-a681-e069a4bc5290 (17.09.2017).

27. Tienda M, Haskins R. Immigrant Children: Introducing the Issue. The Future of Children. 2011; 21(1): 3-18, doi: 10.1353/foc.2011.0010.

28. Uzun EM, Bütün E. Teacher opinions about the problems faced by children with Syrian refugees in pre-primary education institutions. International Early Childhood Education Studies Journal. 2016; 1(1).

29. TuranlıYücel K. Being a refugee and child. Society and Physician. 2007; 22(5): 356-363.

30. Janta B, Harte E. Education of migrant children: Education policy responses for the inclusion of migrant children in Europe. Policy Brief. 2016, doi: 10.7249/rr1655.

31. Topsakal C, Merey Z, Keçe M. A qualitative study on education rights and problems of immigrant families' children. Journal of International Social Research. 2013; 6(27): 546-560.

32. Robila M. The Impact of Migration on Children's Psychological and Academic Functioning in the Republic of Moldova. International Migration. 2012; 52(3): 221-235, doi: 10.1111/imig.12029.

33. Özservet $Y$, Sirkeci E. From the editor: Children and migration. Migration Journal. 2016; 1: 1-4.

34. Johnson N. Deterrence, detention, \& deportation: Child migrants in the United States \& the European Union. Heinrich Böll Stiftung. 2015: 1-13.

35. Farmer $A$. The impact of immigration detention on children. Forced Migration Review. 2013; 44: 14-16.

36. Kirmayer $\mathrm{L}$, Narasiah L, Munoz M, et al. Canadian Collaboration for Immigrant and Refugee Health (CCIRH). Common mental health problems in immigrants and refugees: general approach in primary care. CMAJ. 2011; 183(12): E959-E967, doi: 10.1503/cmaj.090292, indexed in Pubmed: 20603342.

37. Geçkil E, Aldem M, Kaleci E. 2017 Immigration impact on child health. Journal of Human Sciences. 2017; 14(1): 171-186.

38. Turkey: Refugee crisis - General Directorate of European Civil Protection and Humanitarian Aid. ECHO Introduction Document. echo.info. tr/factsheet/7 (17.09.2017).

39. UNICEF. Syrian children in Turkey information note, 26 May 2016. http://www. unicef. org. tr/files/bilgimerkezi/doc. T\% C3\% BCrkiyedeki\% 20Suriyeli, 20, C3 (17.09.2017).

40. UNICEF. Press Center (9/2016). UNICEF: There nearly 50 million children "uprooted" worldwide. http://www.unicef.org.tr/basinmerkezidetay. aspx?id=22688 (17.09.2017). 